\title{
COMPARISON OF DIFFERENT DETERMINING METHODS OF REFERENCE ETO BASED ON LIMITED WEATHER CONDITIONS IN GAP REGION
}

\author{
AYDIN, Y. \\ Department of Biosystem Engineering, Faculty of Agriculture, Siirt University, Siirt, Turkey \\ (e-mail: yusufaydin@siirt.edu.tr; phone: +90-484-212-1111; fax: +90-484-223-1998)
}

(Received $30^{\text {th }}$ Apr 2019; accepted $13^{\text {th }}$ Jun 2019)

\begin{abstract}
Reference crop evapotranspiration $\left(\mathrm{ET}_{\mathrm{o}}\right)$ is among the most important components of the hydrologic cycle. Standard FAO-Penman-Monteith method is the most frequently used equation to estimate of $\mathrm{ET}_{\mathrm{o}}$. However, the usability of this method is limited due to its complexity HargreaveasSamani (HS) and Turc methods that can be operated with limited data such as temperature and solar radiation are used as an alternative to the standard method. In the present study, the reference $\mathrm{ET}_{\mathrm{o}}$ values estimated with FAO-PM as the standard method, Hargreaveas-Samani and Turc methods were compared at semi-arid climate conditions. Based on the acquired results; highest $\mathrm{R}^{2}$ value at the GAP region with semi-arid climate conditions was determined as 0.9872 from the monthly averages of $\mathrm{ET}_{\text {o-PM }}$ and $\mathrm{ET}_{\mathrm{o}-\mathrm{HS}}$ comparison, whereas the lowest RMSE value was also obtained from the same monthly comparison (0.08). $\mathrm{ET}_{\mathrm{o}-\text { Turc }}$ method yielded a monthly average comparison of 0.981 for the $\mathrm{R}^{2}$ values comparison. While $\mathrm{ET}_{\text {o-CAP }}$ put forth the lowest values for all three intervals. It is suggested that HS method can be used instead of Standart Penman-Monteith method (FAO-PM) under GAP region semi arid climate conditions for reference $\mathrm{ET}_{\mathrm{o}}$ estimation if Penman-Monteith can not be calculated. The Turc method is also can be a good alternative to estimate potential evapotranspiration that can be measured by Class A pan. And that $\mathrm{ET}_{\mathrm{o}}$ estimation should be made by determining the $\mathrm{K}_{\mathrm{p}}$ value in case CAP based $\mathrm{ET}_{\mathrm{o}}$ estimation is carried out.
\end{abstract}

Keywords: reference $E T_{o}$, FAO-PM equation, Hargreaves-Samani equation, Turc equation, pistachio

\section{Introduction}

Evapotranspiration is the most important component of the hydrologic cycle and occurs with the mutual impact of evaporation and transpiration from the soil and the leaf. In this regard, it is the most important parameter for water source planning, water budget methods and irrigation software used in crop water consumption calculations. Continuity and high yield in agricultural production is possible only by the accurate and timely completion of losses due to evaporation and transpiration. For this purpose, $\mathrm{ET}_{\mathrm{o}}$ should be estimated accurately since it plays a critical role in the accurate estimation of water losses from the soil and the leaf, carrying out the plans accordingly as well as the planning of irrigation systems (Trajkovic, 2008; Çobaner et al., 2016). Evapotranspiration is generally estimated in two stages. It can be determined by estimating the evaporation gap of the air around the plant subject to certain climate parameters as well as by calculating the water consumption of the grass covering the soil surface completely which is used in estimating plant water consumption $\left(\mathrm{ET}_{\mathrm{c}}\right)$ and multiplying it by a certain coefficient specific to the crop. It is known that there are over 50 methods or models for the estimation of potential evapotranspiration subject to the data sets used (temperature, radiation, Class A Pan, mass transfer etc.), ecological conditions (arid or humid) and assumptions (Lu et al., 2005). Many researchers have tested the compliance of these methods under certain ecological conditions while also carrying out studies for putting forth the performances of difference methods under different climate conditions (Castaneda and Rao, 2005; Tabari et al., 2013). 
Empirical equations based on energy and mass transfer in compliance with different climate and environmental conditions have been developed for estimating $\mathrm{ET}_{\mathrm{o}}$. For this purpose, Allen et al. (1998) developed the FAO-56 Penman-Monteith method (PMF-56) which is the standard method that is widely used all over the world under different climate and agricultural conditions for ensuring that $\mathrm{ET}_{\mathrm{o}}$ estimation is more understandable as well as for ensuring that the information provided is used commonly and frequently (Fisher and Pringle, 2013). This method is widely used for determining reference $\mathrm{ET}_{\mathrm{o}}$ (Çobaner et al., 2016). However, there are difficulties related with the use of this model for estimating ETo due to its complexity. Daily data for many meteorological parameters such as temperature, relative humidity, solar radiation, evaporation, wind speed are required for using this model. It is not always possible to obtain this data set in full due to both technological and human based reasons and due to the fact that it is partially costly. On the other hand, calculation of water consumption on has become difficult in Turkey with a surface area of $783.562 \mathrm{~km}^{2}$ since there are 275 meteorological stations with one station per each $275 \mathrm{~km}^{2}$ (Çobaner et al., 2016). Therefore, researchers have developed easy to use reference ET $_{0}$ methods which can be an alternative method for regions where it is not possible to provide the data set in full. Reference $\mathrm{ET}_{\mathrm{o}}$ should be calculated using methods that require less climate data in cases when sufficient climate data are not available. For this purpose, Todoroviç et al. (2013) suggests the use of the best known Hargreveas-Samani equation and the "Penman Monteith Temperature Method" (PMT) in which the data required for calculation is calculated from the already existing climate data. Hargreavas and Samani (1985) developed an equation that can calculate the reference evapotranspiration value making use of only temperature and radiation data. Similarly, the Turc formula (1961) that uses only radiation, temperature and relative humidity values for determining reference $\mathrm{ET}_{\mathrm{o}}$ was first developed for the regions of Southern France and Northern Africa (Diouf et al., 2016). The fact that the data used can be acquired easily is evaluated as the superiority of this formula for cases when the parameters required by other methods cannot be obtained. In addition, new methods developed which require a smaller data set have been used by many different researchers under different climate conditions for determining their performances in humid ( $\mathrm{Lu}$ et al., 2005; Fisher and Pringle, 2013; Tabari et al., 2013) and arid regions (Todorovic et al., 2013) and for making a comparison with the FAO-56 PM method (Trajkovic, 2008; Gavilan et al., 2006; Castaneda and Rao, 2005; Shahidian et al., 2012). Since the Turc method is an empirical equation developed for estimating reference ET $_{0}$ in humid regions, it uses only temperature and solar radiation as the data set. The radiation term used in this method is solved by the method provided in the Hargreaves-Samani equation. In addition to these methods, methods based on Class A Pan evaporation method as an alternative for many regions in the world where meteorological data cannot be obtained in full are used widely due to their ease of use, low cost and ease of application in irrigation software (Tabari et al., 2013). Different researchers (Kanber et al., 1992; Bilgel et al., 1999; Aydın, 2004) have carried out a limited number of studies on the determination of crop water consumption $\left(\mathrm{ET}_{\mathrm{c}}\right)$ for pistachio. In these studies, $\mathrm{ET}_{\mathrm{o}}-\mathrm{PM}$ method has been used as the standard method for determining reference $\mathrm{ET}_{\mathrm{o}}$. The Food and Agriculture Organization (FAO) declared in 1990 together with the International Irrigation and Drainage Commission and World Meteorological Organization (WMO) that the FAO-PM (Allen et al., 1998) method can be taken as a reference since it yields more consistent and reliable results in comparison with other methods (Castaneda and 
Rao, 2005; Çobaner et al., 2016). Hence, FAO-56-PM method was taken as the standard in this study with which the other methods were compared. Hargreaveas-Samani and Turc equations can be used frequently for crop water consumption calculations since they are easy to use, require less data and can be used only with temperature data. Therefore, some empirical methods used for determining reference crop water consumption and CAP evaporation method were evaluated comparatively in this study. The climate data used for this purpose in the study were acquired from the Provincial directorate of meteorology in Siirt. In this study, climate data and FAO-56 Penman Monteith values which are used as reference method were taken from the study carried out in Gaziantep in order to determine crop water consumption $\left(\mathrm{ET}_{\mathrm{c}}\right)$ in pistachio by Aydın (2004). Gaziantep, one of the most important provinces for pistachio production was selected as the study area. Pistachio is produced in 56 provinces in Turkey (Anonymous, 2001) with the highest amount of production in Gaziantep and Şanliurfa. Gaziantep is ranked first in Turkey with regard to its pistachio production area and product amount (Aslan, 2017) which is an important economical input for the economy of the province. In the aforementioned study, reference $\left(\mathrm{ET}_{\mathrm{o}}\right)$ were determined according to FAO-56 Penman Monteith method and ET $_{c}$ was calculated according to water budget technique. From this point of view, crop coefficients $\left(\mathrm{K}_{\mathrm{c}}\right)$ were determined for the phenological stages of pistachio. The maximum and minimum values of $\mathrm{K}_{\mathrm{c}}$ for the suggested treatment in July and November were calculated as 1.51 and 0.39, respectively. These values range from 0.49 to 1.1 for the Southeast $1^{\text {st }}$ Region (Gaziantep, Şanlıurfa and Diyarbakır) (Anonymous, 2017). However, since it is not always possible to determine the $\mathrm{ET}_{\mathrm{o}}$ by the Penman-Monteith method, it is possible to eliminate this deficiency with the Hargreaves-Samani model and to estimate ET $_{\mathrm{c}}$ using the determined $\mathrm{K}_{\mathrm{c}}$ coefficients. On the other hand, no studies were conducted to determine pan coefficient $\left(\mathrm{K}_{\mathrm{p}}\right)$ for Gaziantep and Southeastern Anatolia region. Similarly, Since a new issue in Southeastern Anatolia Region, there is no study about determination of $K_{p}$ in pistachio. On the other hand, the $K_{p}$ coefficients, which changed periodically for Pistachio in California conditions, were proposed as 0.96 in June and August (Anonymous, 2019). Therefore, $K_{p}$ coefficient was accepted as 1 in this study.

The purpose of the present study was to carry out reference $\mathrm{ET}_{\mathrm{o}}$ estimation in pistachio production regions, carry out reference $\mathrm{ET}_{\mathrm{o}}$ estimations via FAO-PM, Hargreaves-Samani and Turc equations in addition to Class A Pan (CAP) method, evaluate the usability of these methods for alternative reference crop water consumption $\left(\mathrm{ET}_{\mathrm{o}}\right)$ estimation in the GAP region and the put forth the relations between these methods. In addition, this study aims to contribute to the studies on determination of crop coefficient $\left(\mathrm{K}_{\mathrm{c}}\right)$, evaporation pan coefficient $\left(\mathrm{K}_{\mathrm{p}}\right)$ or crop-pan coefficient $\left(\mathrm{K}_{\mathrm{cp} \text {-dual }}\right)$ in Southeast Anatolia region where pistachio is grown widely.

\section{Materials and methods}

\section{Description of study area and weather data}

The city of Gaziantep is located in the Southeast Anatolia Region (Fig. 1) between $36^{\circ} 28^{\prime}$ and $38^{\circ} 0^{\prime}$ ' eastern longitudes and $36^{\circ} 38^{\prime}$ and $37^{\circ} 32^{\prime}$ northern latitudes in WGS84 system and according to ED-50, $3^{\circ}$ Central Meridian (CM): 36 coordinate system was shown in Table 1. 


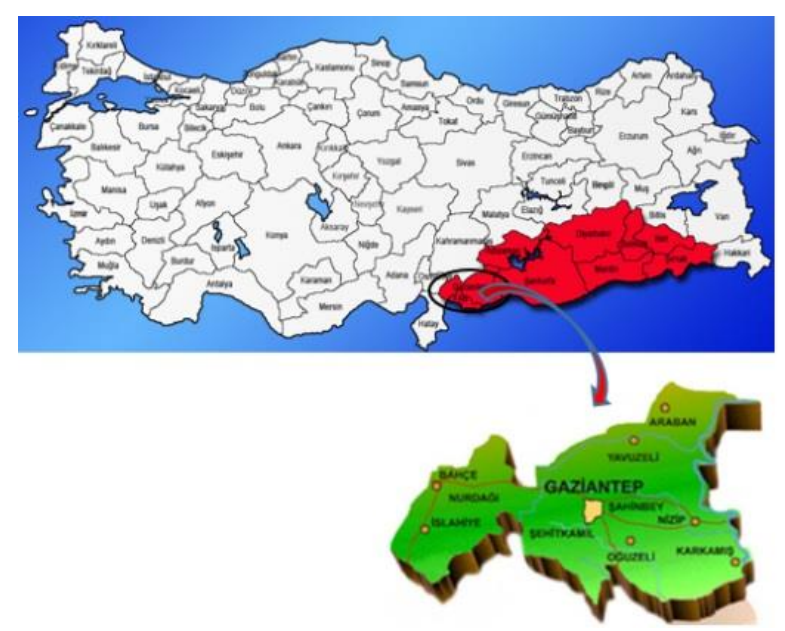

Figure1. Locational view of the study area

Table 1. The place of Gaziantep in ED-50, $3^{\circ} \mathrm{CM}: 36$ coordinate system

\begin{tabular}{c|c|c}
\hline Points & X & Y \\
\hline 1 & 541275.4225986 & 4155978.5921223 \\
2 & 411633.5530552 & 4156345.4115202 \\
3 & 410582.2394373 & 4056459.2749163 \\
4 & 541765.9807594 & 4056095.7171703 \\
\hline
\end{tabular}

Gaziantep has a climate structure with transition characteristics between the Mediterranean and the continental climate. Summers are quite hot and arid, while winters are cold and rainy. Mean annual temperature is $+14.9{ }^{\circ} \mathrm{C}$, with the highest temperature of $+44{ }^{\circ} \mathrm{C}$ and lowest temperature of $-17.5^{\circ} \mathrm{C}$. The hottest month is July with 27.7, while the coldest month is January with 3.4 and the annual rainfall for the province is $544.3 \mathrm{~mm}$. Rains generally occur during the winter period with less rain during the summer months when evapotranspiration is high and the crops need plenty of water (Aydin, 2004). Thus, irrigation operation and management stands out for pistachio production.

\section{ETo estimation methods}

FAO-56 PM method was used in this study for comparing the reference $\mathrm{ET}_{\mathrm{o}}$ estimations obtained via Hargreaveas-Samani and Turc equations. For this purpose, the daily $\mathrm{ET}_{\mathrm{o}-\mathrm{PM}}$ values were used which have been calculated in the study on pistachio by Aydın (2004) and Ünlü (2005). The climate data of Gaziantep, located in Southeastern Anatolia Region which is known as the most important pistachio producing region of Turkey were used in the aforementioned study. Climate data for the same province were used in Hargreaveas-Samani and Turc equations used for estimating reference $\mathrm{ET}_{\mathrm{o}}$.

\section{FAO-56 Penman Monteith method}

The FAO-56 Penman Monteith method used for determining reference crop water consumption requires only daily meteorological data. This equation can be written as indicated below (Allen et al., 1998). 


$$
E T_{0}=\frac{0.408 *\left(R_{n}-G\right)+y_{T+278} u_{2}\left(\theta_{s}-\epsilon_{a}\right)}{\Delta+\gamma 1+0.34 u_{2}}
$$

where $\mathrm{ET}_{\mathrm{o}}$ : reference evapotranspiration $\left(\mathrm{mm} \mathrm{day}^{-1}\right) ; \mathrm{R}_{\mathrm{n}}$ : net radiation $\left(\mathrm{MJ} \mathrm{m}^{-2}\right)$, G: soil heat flux $\left(\mathrm{MJ}_{\mathrm{m}} \mathrm{m}^{-2}\right)$; $\mathrm{T}_{\text {mean: }}$ average air temperature $\left({ }^{\circ} \mathrm{C}\right) ; \mathrm{U}_{2}$ : wind speed at $2 \mathrm{~m}$ height $\left(\mathrm{m} . \mathrm{sn}^{-1}\right), \mathrm{e}_{\mathrm{s}}$ : saturation vapor pressure $(\mathrm{kPa}), \Delta$ : slope of vapor pressure curve $\left(\mathrm{kPa} .{ }^{\circ} \mathrm{C}^{-1}\right)$, $\gamma$ : psycrometric constant $\left(\mathrm{kPa} .{ }^{\circ} \mathrm{C}^{-1}\right)$

$\mathrm{The}_{\mathrm{E}} \mathrm{ET}_{\mathrm{o}}$ software developed by FAO-56 was used for determining reference $\mathrm{ET}_{\mathrm{o}}$. All parameters used in this software are data measured daily and acquired from the meteorological station.

\section{Hargreaves-Samani method}

The Hargreaves-Samani equation used for determining reference crop water consumption which requires only the maximum and minimum $\left(\mathrm{T}_{\max }-\mathrm{T}_{\min }\right)$ temperature values and extraterrestrial radiation (global radiation) $\left(\mathrm{R}_{\mathrm{a}}\right)$ can be indicated as below (Hargreaves and Samani, 1985).

$$
E T_{O-H S}=0.0023 \frac{R_{a}}{\lambda} \sqrt{\left(T_{\max }-T_{\min }\right)}(T+17.8)
$$

$\mathrm{ET}_{\mathrm{o}}$ : Reference evapotranspiration $\left(\mathrm{mm} \mathrm{day}^{-1}\right), 0.0023$ : an empirical coefficient, $\mathrm{R}_{\mathrm{a}}$ : extraterrestrial radiation $\left(\mathrm{mm} \mathrm{day}^{-1}\right), \lambda$ : the latent heat of vaporization $\left(\mathrm{MJ} \mathrm{kg}^{-1}\right)$ for the mean air temperature $\left(\mathrm{T}_{\text {mean }}\right.$ in $\left.{ }^{\circ} \mathrm{C}\right)$ given as:

$$
\lambda=2.501-0.002361 * T_{\text {mean }}
$$

$\lambda$ is generally assumed $2.45{\mathrm{MJ} . \mathrm{kg}^{-1}}^{-1}$

Since the temperature, humidity and radiation values used in the equation can be accessed easily, it has been used by many researchers for determining the reference crop water consumption (Todorovic et al., 2013; Fisher and Pringle., 2013; Djaman et al., 2015; Çobaner et al., 2016; Diouf et al., 2016; Yamaç, 2018). The $\mathrm{R}_{\mathrm{a}}$ value used for calculating $\mathrm{ET}_{\mathrm{o}-\mathrm{HS}}$ was calculated using the following equation suggested by Fisher and Pringle (2013) for the Turc method which is solved subject to temperature and by making use of the solar radiation data obtained from the meteorology.

$$
R_{s}=0.16\left(T_{\max }-T_{\min }\right)^{0.5} R_{a}
$$

$\mathrm{R}_{\mathrm{s}}$ is the solar radiation $\left(\mathrm{MJ} \mathrm{m} \mathrm{m}^{-2} \mathrm{day}^{-1}\right)$.

\section{Turc method}

The Turc formula derived by Turc (1961) which is used for calculating the daily potential evapotranspiration can be written as below:

$$
E T_{\text {o-Turc }}=a * C *\left(R_{G}+b\right) \frac{T}{r+15}
$$


where $\mathrm{ET}_{\mathrm{o}}$ : reference evapotranspiration $\left(\mathrm{mm} \mathrm{day}^{-1}\right), \mathrm{T}$ : mean daily temperature $\left({ }^{\circ} \mathrm{C}\right)$, $\mathrm{R}_{\mathrm{G}}$ : Global radiation $\left(\mathrm{MJ} \mathrm{m} \mathrm{may}^{-1}\right), \mathrm{a}$ and $\mathrm{b}$ : empirical constants and $\mathrm{a}=0.31\left(\mathrm{~m}^{2} \mathrm{MJ}^{-1}\right.$ $\left.\mathrm{mm}^{-1}\right)$ and $\mathrm{b}=2.094\left(\mathrm{MJ} \mathrm{m}^{-2}\right.$ day $\left.^{-1}\right), \mathrm{C}$ : defined by the relative humidity $\mathrm{RH},(\%)$ as:

$$
\begin{gathered}
C=1+\frac{50-\mathrm{RH}}{70} \quad \text { if } R H<50 \% \\
C=1 \quad \text { if } R H \geq 50 \%
\end{gathered}
$$

Similarly, relative humidity and temperature values were obtained from meteorological records of Provincial Directorate of Meteorology in Siirt. The C value in the $\mathrm{ET}_{\mathrm{o}-\mathrm{Turc}}$ equation used for calculating daily potential evapotranspiration was calculated using the aforementioned equations based on the average relative humidity ratio.

\section{Pan evaporation method (ET $\left.\boldsymbol{T}_{o-C A P}\right)$}

The following equation suggested by Allen et al. (1998) was used for calculating reference crop water consumption ( $\mathrm{ET}_{\mathrm{o}}$ ) according to the Class A Pan evaporation method.

$$
E T_{\circ}=K_{p} * E_{\text {pan }}
$$

where $\mathrm{ET}_{\mathrm{o}}$ : Reference evapotranspiration, $\mathrm{mm} \mathrm{day}^{-1} ; \mathrm{K}_{\mathrm{p}}$ : pan coefficient (assumed 1 as average value in this study). $\mathrm{E}_{\mathrm{pan}}$ : pan evaporation, $\mathrm{mm}$ day $^{-1}$. However, the $\mathrm{K}_{\mathrm{p}}$ value was not calculated separately in this comparison and was assumed theoretically as 1 and therefore the measured $\mathrm{E}_{\mathrm{pan}}$ value was assumed to be equivalent to $\mathrm{ET}_{\mathrm{o}}$.

\section{Statistical analysis}

The $\mathrm{ET}_{\mathrm{o}}$ values calculated daily according to the FAO-PM method were compared statistically with the daily $\mathrm{ET}_{\mathrm{o}}$ values. Paired comparisons were made for determining the value of $\mathrm{R}^{2}$ which were then subject to linear regression analysis and the $\mathrm{R}^{2}$ equation was determined for the obtained curve. The equalities suggested by Djaman (2015) which are provided in Table 2 were used for a more advanced evaluation of the compared equations.

\section{Results and discussion}

The climate data for 1999-2002 obtained from the meteorological records were used in the study. For this purpose, the maximum and minimum temperatures used in the Hargreaveas-Samani and Turc equations along with the relative humidity and radiation values used in the Turc equation were evaluated separately for each year and than converted to monthly average (Fig. 2a).

The solar radiation values measured in $\mathrm{cal} \mathrm{cm}^{-2} \mathrm{day}^{-1}$ at the meteorology stations were converted into the unit of $\mathrm{MJ} \mathrm{m}^{-2} \mathrm{day}^{-1}$ after which they were used for solving the equation. The radiation values for the study years are provided in Figure $2 b$ as monthly average annually. As can be seen when the figures are examined, while solar radiation values were low in the beginning of the year (January-February) and in the last two months (November-December) of the year, the number of sunny days and sunshine 
duration along with the amount of reflected radiation increased parallel to the increase in seasonal temperatures. Cloudy weather that sometimes occurred during measurement days appears as sudden decreases in radiation.

Table 2. Statistical analysis equations

\begin{tabular}{|c|c|c|}
\hline Source & Equation & \\
\hline Root mean squared error (RMSE & $R M S E=\sqrt{\sum_{k=0}^{n} \frac{\left(P_{i}-O_{i}\right)^{2}}{n}}$ & (Eq.9) \\
\hline Mean absolute error (MAE) & MAE $=\mathrm{n}-1 \sum_{1}^{n}\left(P_{i}-O_{i}\right)$ & (Eq.10) \\
\hline Percentage error (PE) & $\mathrm{PE}=\left|\frac{P_{\text {ave }}-o_{\text {ave }}}{o_{\text {ave }}}\right| 100 \%$ & (Eq.11) \\
\hline Mean ratio (MR) & $\mathrm{MR}=\mathrm{n}-1 \sum^{\sum_{1}^{n} \frac{P_{i}}{o_{i}}}$ & (Eq.12) \\
\hline $\begin{array}{l}\text { Determination coefficient (R2) } \\
\quad \text { (Todorovic et al., 2013) }\end{array}$ & $R^{2}=\left\{\frac{\sum_{i=1}^{n}\left(O_{i}-\sigma\right) \cdot\left(p_{i}-\tilde{p}\right)}{\sqrt{\sum_{i=1}^{n}\left(O_{i}-\sigma\right)^{2}} \cdot \sqrt{\sum_{i=1}^{n}\left(p_{i}-p\right)^{2}}}\right.$ & (Eq.13) \\
\hline
\end{tabular}

RMSE: root mean squared error; MAE: mean absolute error; MR: mean ratio; PE: percentage error of estimate; $n$ : number of observations, $\mathrm{P}_{\mathrm{i}}$ : estimated $\mathrm{ET}_{\mathrm{o}}$ by other equations, $\mathrm{O}_{\mathrm{i}}$ : $\mathrm{PM}$-estimated $\mathrm{ET}_{\mathrm{o}}$ (actual), $\mathrm{P}_{\text {ave: }}$ mean of the estimated $\mathrm{ET}_{\mathrm{o}}, \mathrm{O}_{\text {ave }}$ : mean of the $\mathrm{O}_{\mathrm{i}}$. In order to determine $\mathrm{R}^{2}$, the pair wise comparisons were made by using linear regression
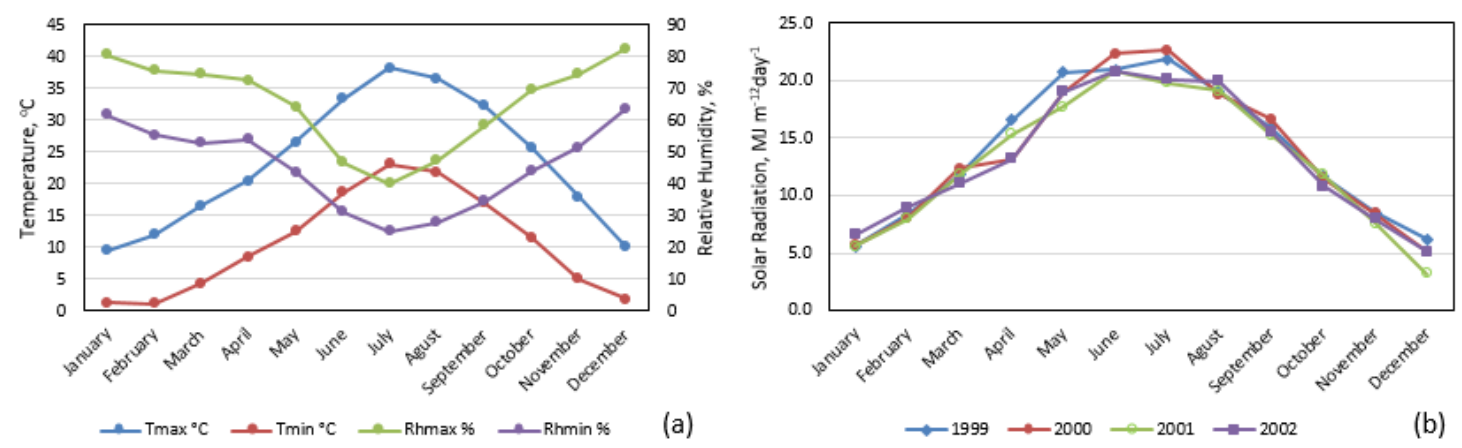

Figure 2. Variation of long-term monthly average temperature and relative humidity $(a)$ and solar radiation during study years $(b)$

The 4 year mean values were calculated for the reference crop water consumption $\left(\mathrm{ET}_{\mathrm{o}}\right)$ daily values obtained via the Hargreaveas-Samani $\left(\mathrm{ET}_{\mathrm{o}-\mathrm{HS}}\right)$, Turc $\left(\mathrm{ET}_{\mathrm{o}-\mathrm{TURC}}\right)$ and Pan evaporation methods (ET $\left.\mathrm{E}_{\mathrm{o}-\mathrm{CAP}}\right)$ compared in the study thereby obtaining long term average and annually total $\mathrm{ET}_{\mathrm{o}}$ values which are presented in Figure $3 a$ and $b$. As shown in Figure $3 a$, in the months which Class A Pan evaporation values measured were taken into consideration to compare the predicted plant water consumption values estimated by the models with the measured values. The period mentioned is the period in which pistachio is phenologically active and in this term, full bloom period is completed and begins the leafout period. The comparison of estimated and measured evaporation values was made until the end of October, which is the post-harvest period. 
Likewise, as shown in Figure $3 b$, the monthly totals of the estimated and measured $\mathrm{ET}_{\mathrm{o}}$ values were calculated for the mentioned period.

(a)

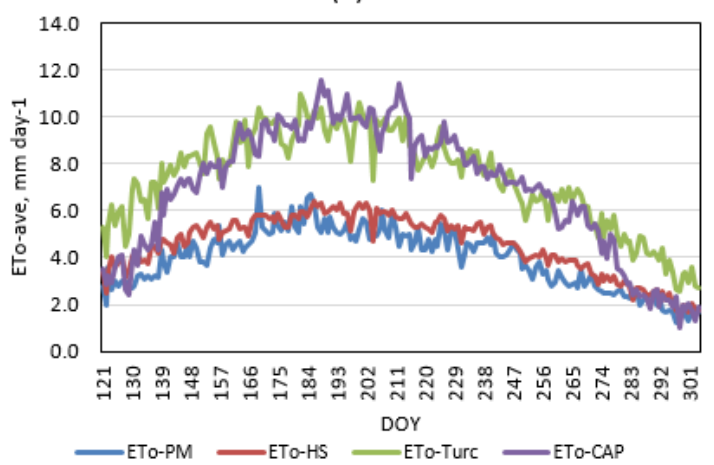

(b)

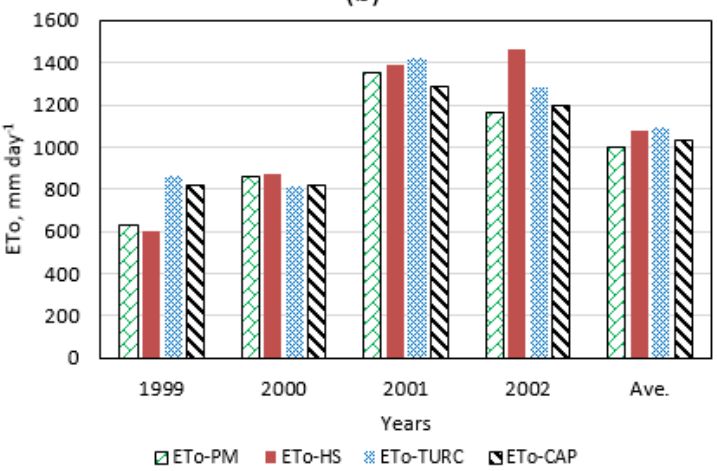

Figure 3. Comparison of 4-year mean daily and total seasonally ET $T_{o}$ calculated from 4 methods during study years for evaporation season

Average daily $\mathrm{ET}_{\mathrm{o}}$ changing during study years. Similarly, The long term monthly mean values were calculated by taking the monthly mean $\mathrm{ET}_{\mathrm{o}}$ values for the same years which are given in Figure 4. As can be seen in Figure 4, $\mathrm{ET}_{\mathrm{o}-\mathrm{PM}}$ and $\mathrm{ET}_{\mathrm{o}-\mathrm{HS}}$ values were determined to be close to each other, however the $\mathrm{ET}_{\mathrm{o}-\mathrm{Turc}}$ and $\mathrm{ET}_{\mathrm{o}-\mathrm{Pan}}$ values were observed to be greater than the $\mathrm{ET}_{\mathrm{o}-\mathrm{PM}}$ and $\mathrm{ET}_{\mathrm{o}-\mathrm{HS}}$ they were compared with. Long term mean monthly mean comparisons have yielded similar results as can be seen in Figure 4. Evaporation measurements are not carried out during the winter months (from November till April) in the study region, however other climate parameters are

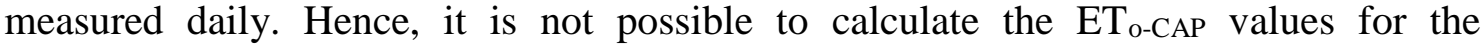
aforementioned months. Çobaner et al. (2016) carried out a study for determining the best Hargreavas-Samani equation for the Mediterranean region as a result of which they put forth that the Hargreavas-Samani equation calibrated according to the temperature and humidity values put forth similar results with those calculated via PenmanMonteith. These findings of the researchers are in accordance with the results of the present study. Small differences in our results are due to the fact that the HS equation has not been calibrated for the GAP region and that it is used directly. Similarly, Trajkovic (2005) states that the Hargreaveas-Samani equation predicts $\mathrm{ET}_{\mathrm{o}}$ higher than the actual value. The average values calculated via $\mathrm{ET}_{\mathrm{o}-\mathrm{CAP}}$ and $\mathrm{ET}_{\mathrm{o} \text {-Turc }}$ methods showed a parallel change, similar to the change of radiation by temperature, as shown in Figure $3 a$. The $\mathrm{ET}_{\mathrm{o}-\mathrm{CAP}}$ values increased rapidly during summer months when evaporation is measured.

Diouf et al. (2016) carried out a study for determining reference $\mathrm{ET}_{\mathrm{o}}$ via Turc equation due to limited climate data under Senegal conditions as a result of which it was reported that the annual $\mathrm{ET}_{\mathrm{o}}$ values were higher for the humid seasons according to the FAO-PM method. The researchers indicated that $\mathrm{ET}_{\mathrm{o}}$ is mostly due to radiation and temperature under conditions of high humidity and that humidity does not have any impact on $\mathrm{ET}_{\mathrm{o}}$ under any circumstance.

Fisher and Pringle (2013) carried out a study under humid regional conditions for comparing the Hargreavas-Samani and Turc methods with the FAO-56 model operated with reduced data as a result of which it was indicated that the FAO-56 reduced dataset 
model yielded better results in comparison with the other two methods. The Turc equation developed for using the measured temperature and radiation value was tested with the equation using estimated radiation values and it was put forth that FAO-56 provides better estimations in comparison with the other methods.

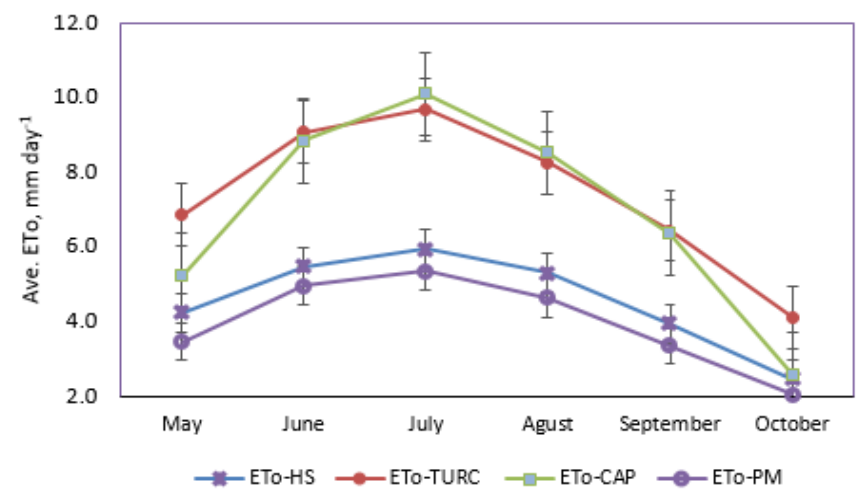

Figure. 4. Comparison of 4-year mean monthly $E T_{o}$ calculated from 4 methods during study years.

Paired comparisons at the daily, 10 days and monthly average value levels were carried out for the reference crop water consumption values calculated in accordance with the methods used and the acquired results are presented graphically in Figures 5-7. As can be seen from Figure 5, the onset of the curve is at low levels during the first months when evaporation measured is not made in winter months while comparing $\mathrm{ET}_{\mathrm{o}}$ PM and $\mathrm{ET}_{\mathrm{o}-\mathrm{CAP}}$ values.

The methods used for reference $\mathrm{ET}_{\mathrm{o}}$ were compared statistically and the acquired results have been summarized in Table 3 .
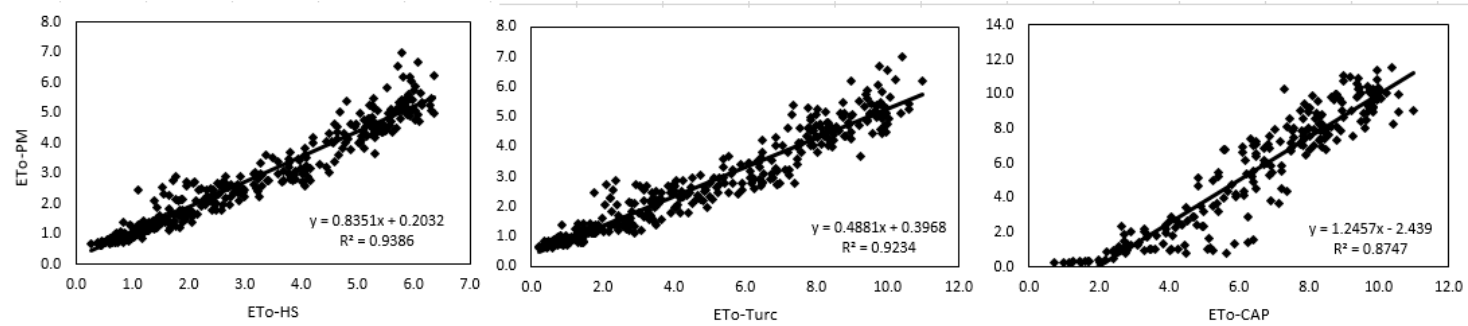

Figure 5. Comparison of daily average ET for (1999-2002)
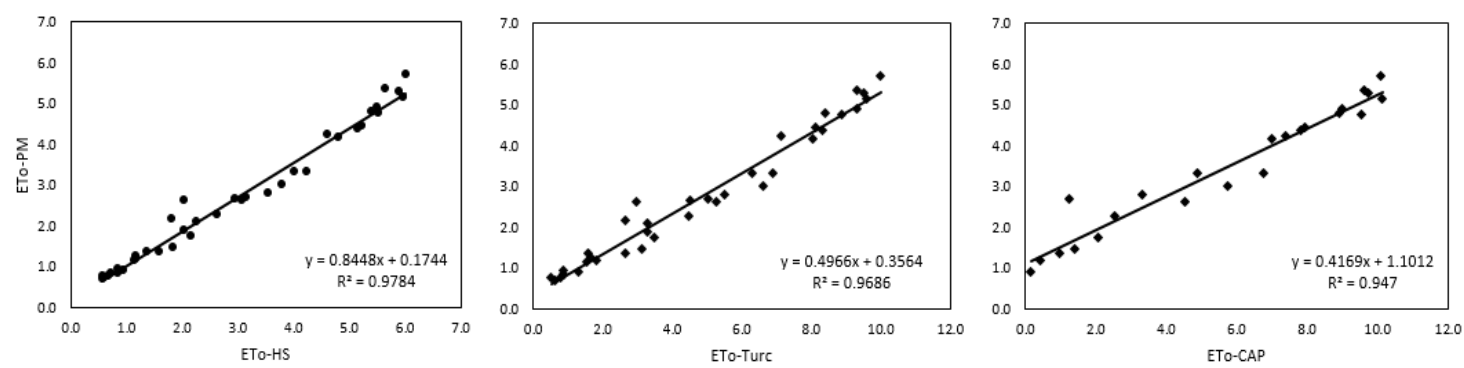

Figure 6. Comparison of 10 days intervals average $E T_{o}$ for (1999-2002) 

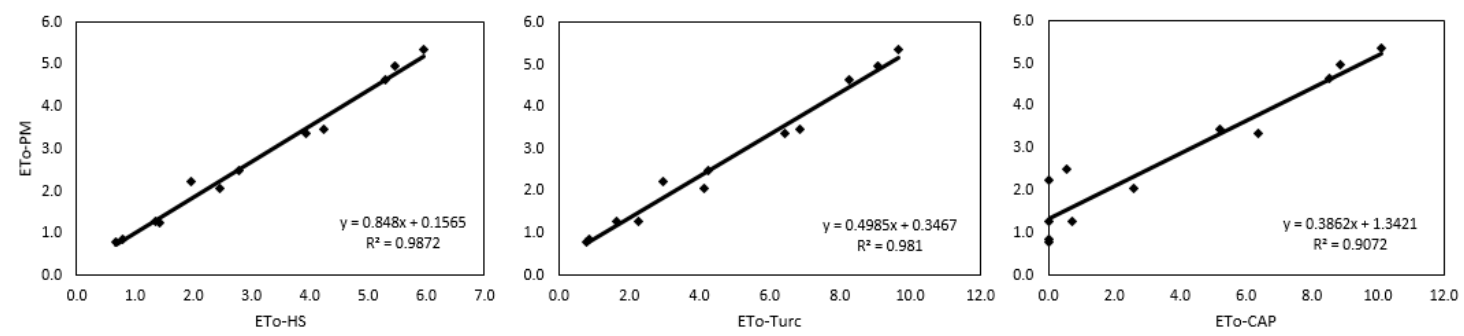

Figure 7. Comparison of monthly average ET for (1999-2002)

Table 3. Error values of average daily ETo estimates on daily basis as compared to FAO-PM method

\begin{tabular}{c|c|c|c|c|c|c|c|c|c}
\hline & \multicolumn{4}{|c|}{ Daily } & \multicolumn{3}{c|}{ 10 days interval } & \multicolumn{3}{c}{ Monthly } \\
\cline { 2 - 10 } & HS-PM & Turc-PM & CAP-PM & HS-PM & Turc-PM & CAP-PM & HS-PM & Turc-PM & CAP-PM \\
\hline RMSE & 0.58 & 2.65 & 2.62 & 0.15 & 0.82 & 0.81 & 0.08 & 0.47 & 0.46 \\
$\mathbf{( m m / d a y )}$ & & & & & & & & & 0.01 \\
MAE (mm) & 0.45 & 2.11 & 2.14 & 0.04 & 0.21 & 0.21 & 0.01 & 0.07 & 0.07 \\
MR & 1.08 & 1.63 & 0.92 & 0.11 & 0.16 & 0.09 & 0.04 & 0.05 & 0.03 \\
$\mathbf{P E ~ ( \% )}$ & 10.84 & 75.09 & 31.96 & 10.73 & 74.80 & 31.51 & 11.15 & 75.07 & 31.39 \\
$\mathbf{R}^{\mathbf{2}}$ & 0.9386 & 0.9234 & 0.8747 & 0.9784 & 0.9686 & 0.947 & 0.9872 & 0.981 & 0.9072 \\
\hline
\end{tabular}

Quantitative methods were applied for carrying out a statistical evaluation of the equations used in $\mathrm{ET}_{\mathrm{o}}$ estimation. It is considered that the $\mathrm{R}^{2}$ value approaching 1 and RMSE, MAE, MR and PE values approaching zero (0) from among the parameters given in Table 3 which are used as criteria for comparing the methods indicate good performance and a high level of accordance between the compared values (Fisher and Pringle, 2013; Kaya et al., 2016).

The $\mathrm{R}^{2}$ values of the studied methods were determined to be close but different in daily, weekly and monthly performance comparisons. It was determined as a result of the comparison made between reference crop water consumption methods for each of the three period intervals that the highest $\mathrm{R}^{2}$ value was obtained as 0.9872 for $\mathrm{ET}_{\mathrm{o}-\mathrm{HS}}$ and $\mathrm{ET}_{\mathrm{o}-\mathrm{PM}}$ at the monthly level, while the lowest $\mathrm{R}^{2}$ value was determined as 0.9386 for the comparison made at the daily level. The lowest $\mathrm{R}^{2}$ value was also obtained as 0.8747 for the $\mathrm{ET}_{\mathrm{o}-\mathrm{PM}}-\mathrm{ET}_{\mathrm{o}-\mathrm{CAP}}$ method as a result of the comparison made for all three periods. Castaneda and Rao, (2005) compared Thornthwaite, Blaney Criddle, Turc and Makkink methods. It was indicated that the Turc method had the best performance among the compared methods since the values obtained were closest to the estimated values of the $\mathrm{ET}_{\mathrm{o}-\mathrm{PM}}$ method prior to recalibration. They also put forth that other $\mathrm{ET}_{\mathrm{o}}$ estimation methods also yield results within acceptable limits close to FAO-PM values in case regional parameters are used and the parameters are calibrated for the region. It will not be misleading to use the HS and Turc methods used in this study for making ET $_{\mathrm{o}}$ estimations in the region. When the compared methods are evaluated according to the RMSE values, lowest RMSE value should be obtained as is the case for other error parameters. As can be seen from the table, while the $\mathrm{ET}_{\mathrm{o}-\mathrm{HS}}-\mathrm{ET}_{\mathrm{o}-\mathrm{PM}}$ pair had the lowest RMSE value for monthly averages with 0.08 , highest RMSE value was obtained as 2.65 from the $\mathrm{ET}_{\mathrm{o}-\mathrm{Turc}}$ and $\mathrm{ET}_{\mathrm{o}-\mathrm{PM}}$ paired comparison. Todorovic et al. (2013) carried out a comparison between $\mathrm{HS}$ and PMT models for reference $\mathrm{ET}_{\mathrm{o}}$ estimation in the 
Mediterranean climate region with limited data as a result of which similar HS and PMT values were obtained for the excessively arid and arid regions with those of MSE. While PMT yielded a lower RMSE value in semi-arid and humid regions as a result of which it was indicated to have a better performance in comparison with HS. It was observed as a result of the percentage error (PE) evaluations that the lowest percentage error was obtained as 10.73 for the 10 day interval comparison, while the highest percentage error was obtained as 75.09 for the $\mathrm{ET}_{\mathrm{o}-\mathrm{Turc}}$ and $\mathrm{ET}_{\mathrm{o}-\mathrm{PM}}$ comparison. Djaman et al. (2015) states that calibrated models display a better performance at cold and hot humid regions thereby leading to monthly values at an acceptable level, while the same performance has not been obtained for the semi-arid and tropical humid regions. Since the models are developed for use in the regional climate conditions for which they have been developed, they yield acceptable results only in similar climate conditions.

It was observed as a result of the statistical comparison between the studied methods that the highest $\mathrm{R}^{2}$ value and the lowest percentage error value were obtained for the $\mathrm{ET}_{\mathrm{o}-\mathrm{HS}}-\mathrm{ET}_{\mathrm{o}-\mathrm{PM}}$ paired comparison in monthly average $\mathrm{ET}_{\mathrm{o}}$ calculation. The results are observed to be in accordance with those of Çobaner et al. (2016) and Todorovic et al. (2013).

\section{Conclusion}

It was determined as a result of the study that the Hargreaveas-Samani model can be used for reference crop water consumption estimation in regions for Penman-Monteith model which full climate data cannot be obtained due to various reasons since these methods can be operated only with limited climate data and maximum temperature, minimum temperature, mean relative humidity and solar radiation inputs. Likewise the Turc model can also be a good alternative to estimate potential evapotranspiration which can be measured by Class A Pan. Moreover, the Penman-Monteith Temperature based (PMT) method used for $\mathrm{ET}_{\mathrm{o}}$ estimation only with temperature data can also be used as an alternative for semi-arid climate conditions such as the GAP region.

\section{REFERENCES}

[1] Allen, R. G., Pereira, L. S., Raes, D., Smith, M. (1998): Crop Evapotranspiration (Guidelines for Computing Crop Water Requirements). - FAO-56 Irrigation and Drainage Paper No: 56. FAO, Rome.

[2] Anonymous (2001): Pistachio Breading. - Pistachio Research Institute Directorate. Publication Number: 13. Gaziantep-Turkey (in Turkish).

[3] Anonymous (2017): Water Consumption of Irrigated Crops in Turkey. - Ministry of Food Agriculture and Livestock, General Directorate of Agricultural Research and Policies, Ankara (in Turkish).

[4] Anonymous (2019): http://cekings.ucanr.edu/. - Date of access: $27^{\text {th }}$ May 2019.

[5] Aslan, N. (2017): Pistachio production in the world and Turkey. - The Journal of Pistachio Research 6: 2-5 (in Turkish).

[6] Aydin, Y. (2004): The effect of different irrigation water and nitrogen levels on yield and alternate bearing in pistachio. - Ph.D Thesis. Çukurova Uni. Institute of Natural and Applied Science. Department of Agriculture Structure and Irrigation (in Turkish).

[7] Bilgel, L., Dağdeviren, İ., Nacar, A. S. (1999): Determination of water consumption and irrigation program of pistachio (Siirt cultivar) in Harran Plain conditions of the GAP 
region. - III. Horticultural Plant Congress of Turkey, Sep, 14-17, Ankara, pp. 252-257 (in Turkish).

[8] Castaneda, L., Rao, P. (2005): Comparison of methods for estimating reference evapotranspiration in southern California. - Journal of Environmental Hydrology 13: 110.

[9] Çobaner, M., Çıtakoğlu, H., Haktanır, T., Yelkara, F. (2016): Determination of Hargreaves-Samani equation for the Mediterranean region. - Dicle Üniversity, Faculty of Engineering, Journal of Engineering 7(2): 181-190 (special issue, in Turkish).

[10] Diouf, O. C., Weihermüller, L., Ba, K., Faye, S. C., Faye, S., Vereecken, H. (2016): Estimation of Turc reference evapotranspiration with limited data against the PenmanMonteith formula in Senegal. - Journal of Agriculture and Environment for International Development - JAEID 110(1): 117-137 DOI: 10.12895/jaeid.20161.417.

[11] Djaman, K., Balde, A. B., Sow, A., Muller, B., Irmak, S., N'Diaye, M. K., Manneh, B., Moukoumbi, Y. D., Futakuchic, K., Kazuki Saito, S. (2015): Evaluation of sixteen reference evapotranspiration methods under sahelian conditions in the Senegal River Valley. - Journal of Hydrology: Regional Studies 3: 139-159. www.elsevier.com/locate/ejrh.

[12] Fisher, D. K., Pringle III, H. C. (2013): Evaluation of alternative methods for estimating reference evapotranspiration. - Agricultural Science 4(8A): 51-60. http://dx.doi.org/10.4236/as.2013.48A008.

[13] Gavilan, P., Lorite, I. J., Tornero, S., Berengena, J. (2006): Regional calibration of Hargreaves equation for estimating reference ET in a semiarid environment. Agricultural Water Management 81: 257-281.

[14] Hargreaves, G. H., Samani, Z. A. (1985): Reference crop evapotranspiration from ambient air temperature. - American Society of Agricultural Engineers, Hyatt Regency, Chicago IL 1985 Winter Meeting, December 17-20, Paper No: 85-2517.

[15] Kanber, R., Önder, S., Köksal, H. (1992): Investigation of pistachio yield and water consumption in southeastern Anatolia conditions. - First International Symposium on Pistachio of Turkey, Gaziantep, pp. 145-160 (in Turkish).

[16] Kaya, S., Evren, S., Daşc1, E. (2016): Comparison of various equations for prediction of class A pan evaporation in semi-arid climatic conditions. - Uludağ Uni. Journal of Agriculture Faculty 30(2): 1-9 (in Turkish).

[17] Lu, J., Sun, G., McNulty, S. G., Amatya, D. M. (2005): A comparison of six potential evapotranspiration methods for regional use in the southeastern United States. - Journal of the American Water Resources Association 41: 621-633.

[18] Shahidian, S., Serralheiro, R., Serrano, J., Teixeira, J., Haie, N., Santos, F. (2012): Hargreaves and Other Reduced-Set Methods for Calculating Evapotranspiration. - In: Irmak, A. (ed.) Evapotranspiration-Remote Sensing and Modeling. InTech, Morn Hill, pp. 59-80. DOI: $10.5772 / 725$.

[19] Tabari, H., Grismer, M. E., Trajkovic, S. (2013): Comparative analysis of 31 reference evapotranspiration methods under humid conditions. - Irrigation Science 31: 107-117.

[20] Todorovic, M., Karic, B., Pereira, L. S. (2013): Reference evapotranspiration estimate with limited weather data across a range of Mediterranean climates. - Journal of Hydrology 481: 166-176.

[21] Trajkovic, S. (2005): Temperature-based approaches for estimating reference evapotranspiration. - Journal of Irrigation Drainage Engineering 131(4): 316-323.

[22] Trajkovic, S., Stojnić, V. (2008): Simple daily $E T_{\mathrm{o}}$ estimation techniques. - Facta Universitatis Series: Architecture and Civil Engineering 6(2): 187-192. DOI: 10.2298/FUACE0802187T.

[23] Turc, L. (1961): Water requirements assessment of irrigation, potential evapotranspiration: simplified and updated climatic formula. - Annales Agronomiques 12: $13-49$. 
[24] Ünlü, M., Kanber, R., P. Steduto, P., Aydın, Y., Diker, K. (2005): Effects of different water and nitrogen levels on the yield and periodicity of pistachio (Pistachia vera L). Turkish Journal of Agriculture and Forestry Sciences 29: 39-49.

[25] Yamaç, S. S. (2018): Estimation of long term reference evapotranspiration using limited weather data in sugar beet plantation area from Middle Anatolian, Turkey. - Süleyman Demirel Üniversity, Journal of Agriculture Faculty (1. International Congress on Agricultural Structure and Irrigation) Special Number: 160-1165. 